UMIT KEMALETTIN TERZI, Ph.D. ${ }^{1}$

(Corresponding Author)

E-mail: terzi@marmara.edu.tr

HUSEYIN ENES ILHAN, M.Sc. Student ${ }^{2}$

E-mail: ilhanh19@itu.edu.tr

HABIB KAYMAZ, Ph.D. ${ }^{3}$

E-mail: habib.kaymaz@daimler.com

HASAN ERDAL, Ph.D. ${ }^{1}$

E-mail: herdal@marmara.edu.tr

HUSEYIN ÇALIK, Ph.D. ${ }^{4}$

E-mail: hcalik@istanbul.edu.tr

${ }^{1}$ Department of Electric and Electronics Engineering

Faculty of Technology, University of Marmara

34722, Kadikoy /Istanbul, Turkey

2 ITU Graduate School of Science, Engineering

and Technology

Ayazaga Kampusu, 34469 Maslak /Istanbul, Turkey

${ }^{3}$ Mercedes Benz Turk AS, Development Bus

34519 Esenyurt /Istanbul, Turkey

${ }^{4}$ Vocational School of Technical Sciences,

Department of Electric

34500, Buyukcekmece/Istanbul, Turkey
Transport Telematics

Review

Submitted: 2 May 2019

Accepted: 27 Nov. 2019

\title{
A REVIEW OF COMMERCIAL ELECTRIC VEHICLE CHARGING METHODS
}

\section{ABSTRACT}

Electric Vehicles (EVS) are rapidly becoming the forerunners of vehicle technology. First electric vehicles were overlooked because of not having adequate battery capacity and because of low efficiency of their electric motors. Developing semiconductor and battery technologies increased the interest in the EVS. Nevertheless, current batteries still have insufficient capacity. As a result of this, vehicles must be recharged at short distances (approximately $150 \mathrm{~km}$ ). Due to scheduled departure and arrival times EVs appear to be more suitable for city buses rather than regular automobiles. Thanks to correct charging technology and the availability of renewable energy for electric buses, the cities have less noise and $\mathrm{CO}_{2}$ emissions. The energy consumption of internal combustion engines is higher than of the electric motors. In this paper, studies on the commercial electric vehicle charging methods will be reviewed and the plug-in charging processes will be described in detail. This study strives to answer the questions of how plug-in charging process communication has performed between the EV and Electric Vehicle Supply Equipment (EVSE).

\section{KEY WORDS}

electric bus; transport and society; charging methods of electric buses; communication protocols of electric vehicle charging systems; safety;

\section{INTRODUCTION}

In recent years, the revelation that emission gas rates of the diesel motors have been changed by software, disobeying the Kyoto protocols [1], has increased the interest in electric vehicles. In the upcoming fifty years, the human population is expected to rise from 7.5 to 10 billion, and the number of Internal Combustion Engine (ICE) vehicles from 700 million to 2.5 billion [2]. It is estimated that the existing oil resources can only be used for 50 more years if consumed at the current consumption rates [3]. The dependence on fossil fuels can be reduced by EVs, thus, decreasing the impact of transportation emissions on the climate change. EVs are more energy-efficient than ICE vehicles. It is forecast that the sale of EVs will increase in the coming years. If we compare EVs and ICE vehicles, EVs might reduce the global air pollution especially in rural areas [1]. However, the European Environment Agency (EEA) has estimated that electric vehicles could account for between $4 \%$ and $5 \%$ of total electricity consumption in 2030 [4]. EVs do not use fossil fuels for charging batteries, but power plants might use fossil fuels for generating electricity for those batteries. If we cannot apply green energy strategies 


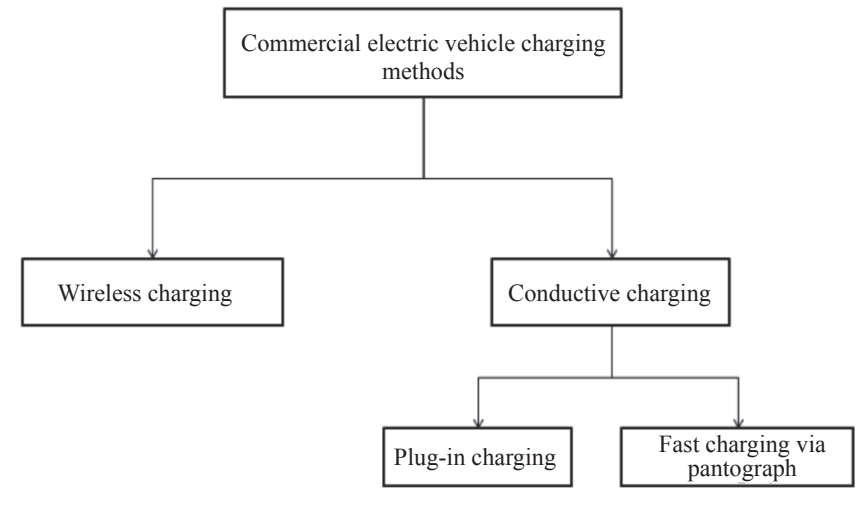

Figure 1 - Commercial electric vehicle charging methods

the air pollution will continue to be a significant problem [5]. For a reliable future for EVs in the commercial sector, some important issues should be resolved. The driving range of battery-electric buses is a constraint and the charging process requires a certain amount of time [6]. Improving battery technology provided a higher range for electric vehicles, but the duration of the charging process increased. To eliminate long charging times, quick charging technology has been developed. However, quick charging technology has some negative effects on the grid [7]. Short-term peak values of instantaneous charging power may demand excessive power from the grid. Many studies are analyzed about changes occurring on the grid, which resulted in dividing the charging options of electric vehicles into two subsections. This paper studies the Mode 4 charging system and the Combined Charging System (CCS). Charging methods of electric vehicles are shown in Figure 1.

For charging electric vehicles IEC 15118 standard has been developed [8]. The standard is mainly focused on the plug-in charging process.

\section{CONDUCTIVE CHARGING}

The conductive charging process can be explained with electrodes. Conductive charging can be divided into two main parts: Plug-in and Pantograph Fast Charging systems.

\subsection{Plug-in charging system}

The plug-in charging system is performed by connectors, cables, and sockets. The type and magnitude of the current transmitted via cable can be different. Due to these differences, variable types of charging cables are generated. In IEC 62196 standard, charging cables, sockets and connectors have been explained according to the charging power. Charging of EVs can be performed via AC or DC [9].

According to the International Electrotechnical Commission (IEC), there are four types of charging modes [10]:

Mode-1: Slow charging via a standard electrical socket without any communication or safety prevention.

Mode-2: Slow charging via a regular socket but with some EV-bounded safety and communication prevention.

Mode-3: Slow or fast charging using a specific and dedicated multi-pin socket with control and protection equipment.

Mode-4: Fast DC charging using some special charger technology.

Depending on the charging power, EVs can be connected to the grid directly or via a piece of equipment. The equipment is also known as EVSE [10]. EVSE is a broad term defining all the grounding and non-grounding equipment, electric vehicle connectors, attachment plugs and all other kinds of accessories needed for charging the EVs. The most important feature is the two-way communication between the charging unit and the vehicle [11]. According to the
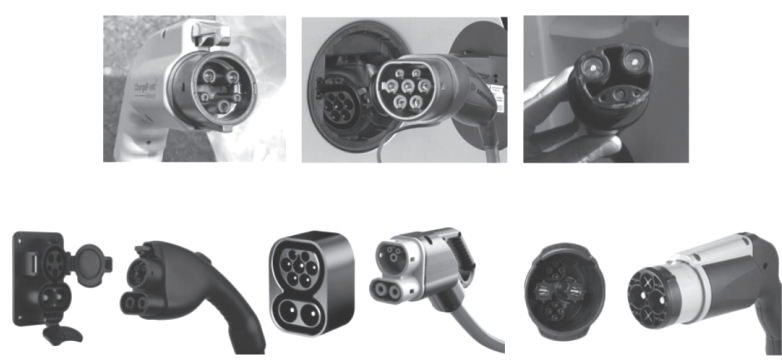

Figure 2-AC and DC plug types, images taken from [13] 
Terzi UK, Ilhan HE, Kaymaz H, Erdal H, Çalik H. A Review of Commercial Electric Vehicle Charging Methods

Table 1-AC/DC charging plugs, maximum power values in Europe and US standards [12, 8]

\begin{tabular}{|c|c|c|c|c|c|}
\hline & Plug & Pin numbers & $\begin{array}{c}\text { Charging } \\
\text { level }\end{array}$ & $\begin{array}{l}\text { Voltage }[\mathrm{V}] / \\
\text { Current }[\mathrm{A}] \\
\end{array}$ & $\begin{array}{l}\text { Max. power } \\
{[\mathrm{kW}]}\end{array}$ \\
\hline \multirow{2}{*}{ USA } & \multirow{2}{*}{$\begin{array}{c}\text { Type } 1 \\
\text { SAE J1772 }\end{array}$} & \multirow{2}{*}{$\begin{array}{c}3 \text { power pins }-\mathrm{L} 1, \mathrm{~N}, \mathrm{E} \\
2 \text { control pins }-\mathrm{CP}, \mathrm{PP}(\mathrm{PWM})\end{array}$} & AC level 1 & $\begin{array}{l}\text { Mono-phase, } \\
120 / \max .16\end{array}$ & 1.9 \\
\hline & & & AC level 2 & $\begin{array}{l}\text { Mono-phase, } \\
240 / \max .80\end{array}$ & 19.2 \\
\hline Europe & Type 2 & $\begin{array}{c}5 \text { power pins }-\mathrm{L} 1, \mathrm{~L} 2, \mathrm{~L} 3, \mathrm{~N}, \mathrm{E} \\
2 \text { control pins }-\mathrm{CP}, \mathrm{PP}(\mathrm{PWM})\end{array}$ & AC level 2 & $\begin{array}{l}\text { Three-phase, } \\
400 \text { / max. } 32\end{array}$ & 22 \\
\hline \multirow{3}{*}{ SAE } & \multirow{3}{*}{$\begin{array}{l}\text { Type } 4 \\
\text { CCS }\end{array}$} & \multirow{3}{*}{$\begin{array}{c}3 \text { power pins }-\mathrm{DC}+, \mathrm{DC}-, \mathrm{E} \\
2 \text { control pins- } \mathrm{CP}, \mathrm{PP}(\mathrm{PLC} \text { and } \mathrm{PWM})\end{array}$} & DC level 1 & $\begin{array}{l}200-450 \mathrm{DC} / \\
\max .80\end{array}$ & 36 \\
\hline & & & DC level 2 & $\begin{array}{l}200-450 \mathrm{DC} / \\
\max .200\end{array}$ & 90 \\
\hline & & & DC level 3 & $\begin{array}{l}200-600 \mathrm{DC} / \\
\max .400\end{array}$ & 24 \\
\hline \multirow[t]{2}{*}{ CHAdeMO } & $\begin{array}{c}\text { Type } 4 \\
\text { CHAdeMO }\end{array}$ & $\begin{array}{c}3 \text { power pins }-\mathrm{DC}+, \mathrm{DC}-\mathrm{E} \\
7 \text { control pins }-\mathrm{CAN} \text { communication }\end{array}$ & DC level 3 & $\begin{array}{l}200-500 \mathrm{DC} / \\
\max .125\end{array}$ & 62.5 \\
\hline & Tesla US & $\begin{array}{l}3 \text { power pins }-\mathrm{DC}+, \mathrm{DC}-, \mathrm{E} \\
2 \text { control pins }-\mathrm{CP}, \mathrm{PP}\end{array}$ & DC level 3 & $\begin{array}{c}400 \mathrm{DC} / \max . \\
300\end{array}$ & 120 \\
\hline
\end{tabular}

Society of Automotive Engineering (SAE), charging plugs can be divided into four main groups: Type 1, Type 2, Type 3, and Type 4 [12].

There are two international connector types for Mode- 4 charging. CHAdeMO is the first system for DC plug-in charging process and Combined Charging System (CCS) is another variation that followed it. Control and communication protocols differ from each other. The CCS uses PWM and Power Line Communication (PLC) over the control pin and for accurate positioning of the charger plug it also uses the proximity pin, while CHAdeMO uses the Controller Area Network (CAN) Bus communication for control and communication via seven pins [13].

\section{CHAdeMO system}

CHAdeMO is the first system for DC charging and it is also known as CHAdeMO Standard. CHAdeMO Sequence Circuit and CHAdeMO pin assignment are respectively shown in Figure 3. CHAdeMO included in IEC 62196 as Type 4 connector. In the CHAdeMO system, data connection is made via CAN Bus communication protocol in addition to carrying DC power [14].

Muhammad Aziz and Takuya Oda studied the charging behaviour of the EVs. The charging test is conducted using a CHAdeMO fast charger. Fast charging during higher ambient temperature produces a significantly higher charging rate, and therefore, shorter charging time [15].

\section{CCS (Combined Charging System)}

The Society of Automotive Engineers (SAE), the European Automobile Manufacturers Association (ACEA) and several automotive manufacturers (Audi, BMW, Daimler, Ford, General Motors, Porsche, and Volkswagen) have developed the CCS as a new global EV charging system. The CCS has two connector types, CCS Type 1 and CCS Type 2. Thanks to these connectors, EVs can be charged to up to 50-350 kilowatts. CCS Type 1 inlet was invented by Kiyoshi Osawa [16].

CCS Type 1 and CCS Type 2 inlets are displayed in Figures $4 a$ and $4 b$. The main difference between these inlet types is the phase-type of AC. CCS Type 1 system can be used in applications of EV charging via mono-phase and CCS Type 2 for three phases. CCS Type 1 system is also proper for US electric vehicles, while CCS Type 2 is only proper for Europe.

HomePlug Green PHY technology and PLC protocol have selected SAE and the ACEA for the communication standard of CCS [17].

CCS Communication Systems: to ensure the safety and correct charging, a communication channel should be placed between the EV and the EVSE. The current information of the EVs, termination, and initiation of the charging process are transmitted via this channel. There are 2 types of communication in the CCS. 


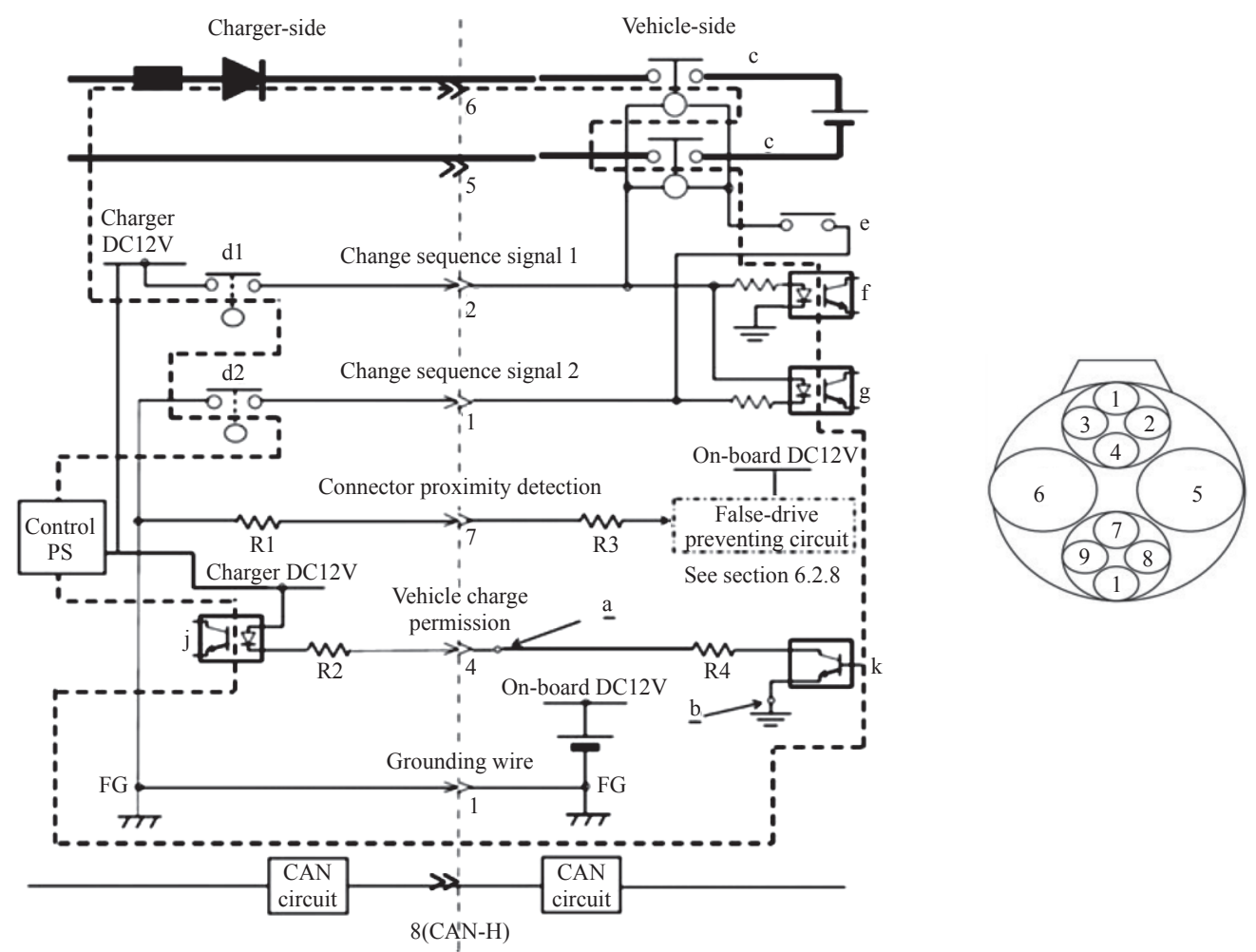

Figure 3 - CHAdeMO sequence circuit (on the left) and Pin assignment of the CHAdeMO [14]

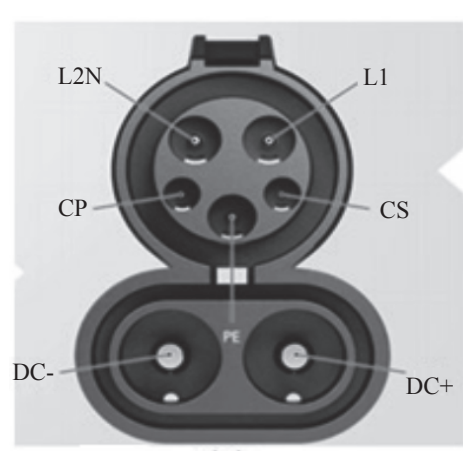

a)

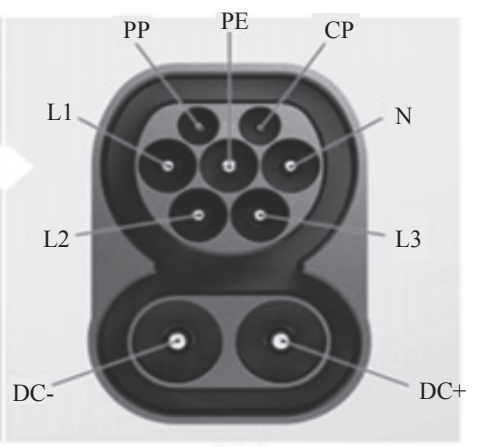

b)
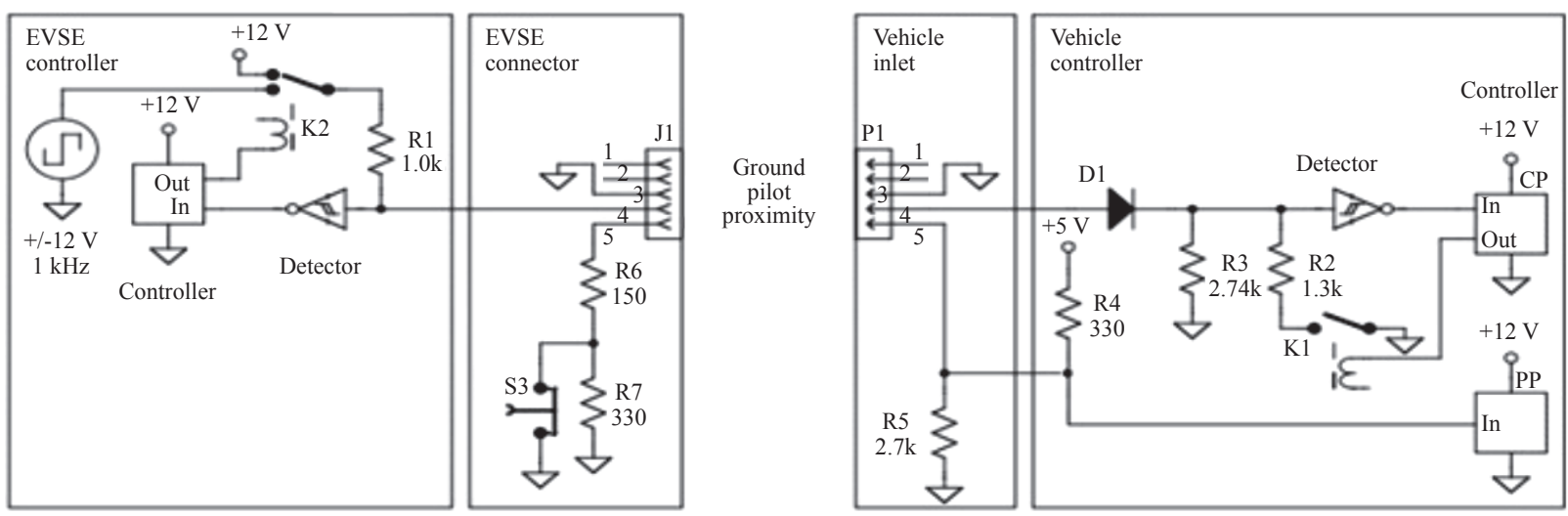

c)

Figure 4-a) Pin assignment of CCS Type 1 inlet, (b) Pin assignment of CCS Type 2, (c) Basic level communication circuit of CCS [18] 
Basic Level Communication: Figure 4c illustrates the basic level communication circuit between the EV and EVSE. The basic communication control is performed by a square wave from the pilot pin [18]. The amplitude of the square wave indicates the state of charging. The duty cycle of the square wave shows the current information drawn in the $\mathrm{AC}$ charging process, while in the DC charging process it shows the performing of high-level communication [19].

High-level Communication: In the DC charging of the CCS, after the initial messaging between the EV and EVSE has been completed, the duty cycle value of the basic level communication signalling is set to 5\% and signalling with PLC is initiated [19].

M. A. Mannah et al. controlled the motor speed with PLC over the PWM network [20].

Christian Lewandowski et al. realized that the PLC signal on the PWM channel generates the voltage peaks at the control pilot and that these peaks may cause excessive limit values for the communication channel specified in IEC 61851-1 [21].

In another study by Christian Lewandowski et al. the communication channel that is located between EVSE and the EV was monitored by HomePlug Green AV technology [22]. The effects of the PLC signal in the PWM channel were investigated and the optimal operating range was determined.

PLC can be regarded as a Media Access Control (MAC) substrate between the data link and physical layer of OSI layers [23].

Yuan-Hua Zhang et al. studied the use of the PLC technique in the communication network within the vehicle [24]. For communication between Electronic Control Units (ECU) the CAN bus protocol was

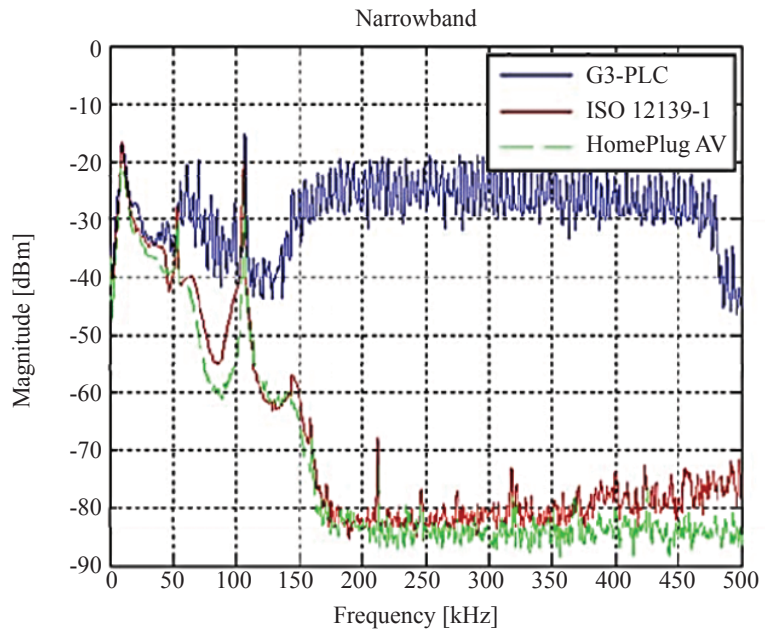

used [25]. This communication protocol requires the use of two extra cables for communication. The heaviest part of the vehicles after the engine are the cables; so, by using the PLC system, the aim is to reduce the vehicle weight. The vehicle engine speed, oxygen level, and water temperature data are transmitted over the PLC system [24].

M. Antoniali et al. tested and analyzed the PLC channels on ships [26].

Joong-Geun Rhee et al. studied the electromagnetic interference in the high-frequency band of the PLC system. According to the results, the PLC system can be used in a high-frequency band following the radio laws [27].

Chang-Un Park et al. studied the analysis of the implementation of the PLC system on broadband and narrowband, and the communication of the vehicle and EVSE on the power line. Figure 5 shows how the noise in the power line affects the PLC signal in a wideband and narrowband. In the narrowband, it is very difficult to guarantee the efficient transmission of PLC signals over the power line [28].

If the PLC signal is transmitted over the power line, noise can be observed in the frequency band, because the power line is connected to the electronic equipment inside the EV (Battery Management System, Inverter, DC/DC converter) [28].

\subsection{Fast charging via pantograph}

DC fast-charging system via pantograph can be considered as an optimized state for the electric trolleybuses, for which the energy distribution system disrupts urban planning. The system is suitable for city buses. Trolleybuses have been energized from long electric distribution lines but on DC

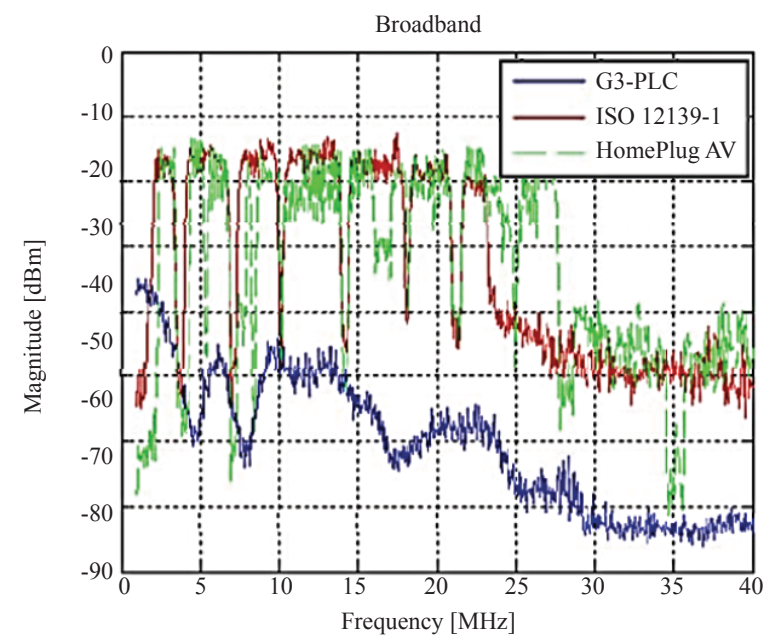

Figure 5 - Power line noise spectrum and PLC signal [28] 
fast-charging process when vehicles arrive at the station short-term and high-power energy flow is initiated from station to vehicle. With this energy, the batteries are charged until the next station.

Soodeh Negarestani et al. studied the optimal storage size of the fast-charging station [29]. In that paper, they investigated harmonics that were generated by rectifiers and they developed a PI controller to overcome the harmonics.

David Steen and Le Anh Tuan studied the effects of electric buses on DC fast-charging stations in the urban grid and also they investigated the maximum power demand of fast charging stations [30].

Robert Prohaska et al. studied electric buses on the bus line 291 between La Verne and Pomona [31]. Twelve BE35 model electric buses were bought from Proterra Inc. in 2013 for the 291 bus line. For testing, the vehicles were driven on a $142,605 \mathrm{~km}$ range route.

The average temperatures are taken from the National Oceanic and Atmospheric Administration (NOAA) for the Ontario International Airport, which is approximately $15 \mathrm{~km}$ away from the electric buses charged. Figure 6 shows that the efficiency of vehicles is maximum when the ambient temperature is close to room temperature. The monthly efficiency of the buses fluctuates relative to average temperatures. When the ambient temperatures are higher, the buses require the use of air conditioning while they require heaters when the temperatures drop.

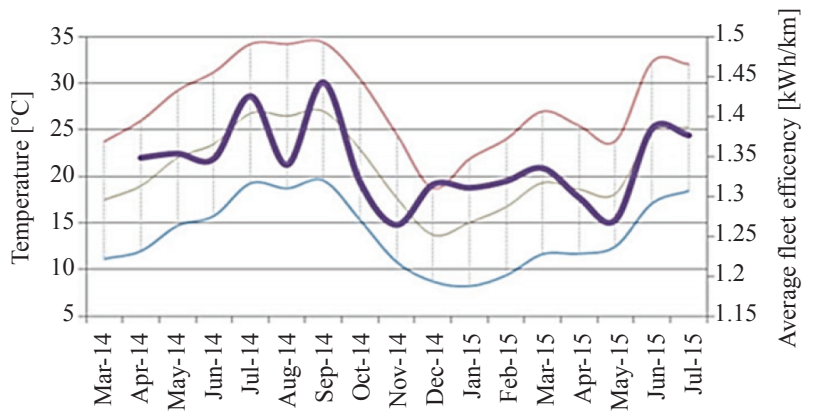

\footnotetext{
- Monthly mean high temperature _ Monthly mean low temperature - Monthly mean temperature _ Monthly BEB efficency
}

Figure 6-Ambient temperature effects on efficiency [31]

Zhenga Gong et al. invented a system that included a method and an apparatus for operating an ultra-capacitor powered vehicle. The invention, in one aspect, includes an electric vehicle powered by ultra-capacitors. The vehicle includes a current collector device for collecting power from an external power source, an electric motor module for providing a driving force to the vehicle, an ultra-capacitor module, and a charger device. The charger has two main parts: Insulated Gate Bipolar Transistor (IGBT) device, and a control device. The control device can be configured to adjust the delivered power by the IGBT device to the ultra-capacitor module based on the temperature signal [32].

Morrissey et al. studied the actual charging behaviour in Ireland [33]. According to the results of their study, fast charging infrastructure is most likely to become commercially viable in the short- to medium-term based on current charging frequency.

On the DC fast charging via the pantograph process, the manufacturers used Wi-Fi protocols for the communication between EV and the charger.

\subsection{EVSE modelling and possible effects}

There are some studies for simulating EVSEs on MATLAB and the relevance of subsystems to these equipment efficiency. Arnaldo Arancibia and Kai Strunz studied modelling for electric vehicle charging stations. Every component is performed on the modelling with the corresponding parameters. The implementation of the model is developed by using Matlab / Simulink SimPowerSystems [34]. They presented a new model charging station for DC charging and explained the charging procedure.

Ganta Naveen et al. studied the modelling of electric vehicle charging stations and simulated it in MATLAB [35]. Figure 7 (top) illustrates the circuit modelling in Matlab / Simulink. In this project, three-phase $\mathrm{AC}$ is the input of the charging station. The AC/DC conversion process is made by the inverter by LC and transformer interface. The appropriate capacitor is fitted on the DC side to meet the sudden and high-power requirements.

LC filter reduces the harmonics between the vehicle and the grid. Buck-boost bidirectional $\mathrm{DC} / \mathrm{DC}$ converter is used in the circuit model. The block diagram of the inverter control system is displayed in Figure 7 (bottom). The inverter control system is a PI-controlled PWM generator and it is used to perform constant DC voltage. They introduced general faults and implemented a protection scheme for preventing possible faults in modelling EVSE [36].

Some studies mainly focused on the possible effects of EVs on the city grid systems. Tapon $\mathrm{Ku}-$ mar Paul and Hideyuki Aisu studied the impact of the increase of EVs on the grid. If $50 \%$ of vehicles 

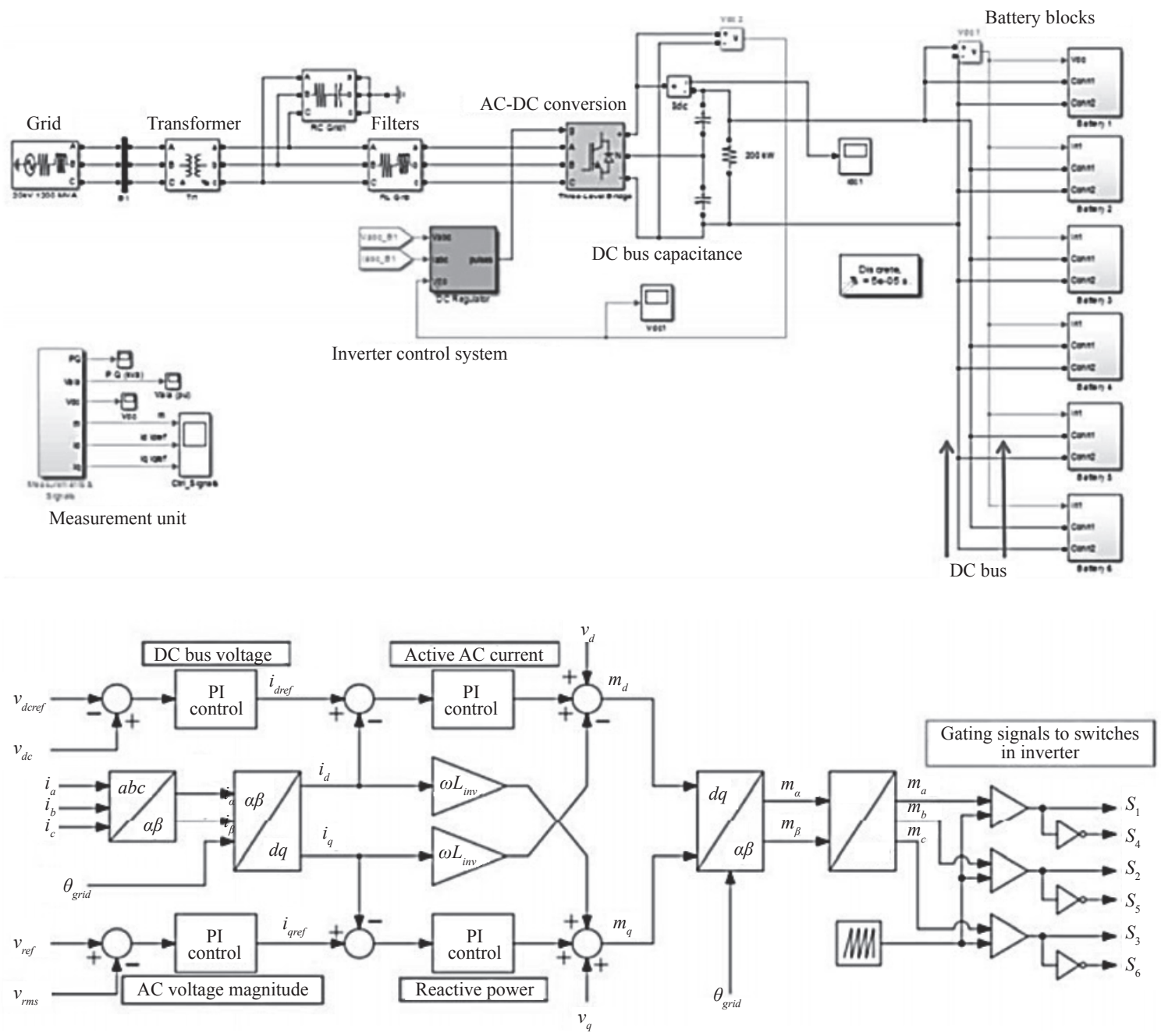

Figure 7 - Plug-in EVSE (top) and control system of inverter modelling (bottom) images taken from [36]

in the Tokyo area transformed into EVs and approximately half of them performed fast-charging processes at the same time, it is estimated that 7.3 GW additional power supply would be required [36].

Shengnan Shao et al. studied the negative effects of Plug-in Hybrid Electric Vehicles (PHEV) on the grid. According to the study, all scenarios of these vehicle charging processes produce additional loads on the distribution transformers. Because of these additional loads, the efficiency of distribution transformers decreases and overloads the transformer [37].

EVSEs increase to the peak load of the grid, increasing the loss of power, degradation on voltage profile and transformers [38].

T. Thiringer and Saeid Haghdin studied the measurement results of the EVSE and analyzed them. They concluded that there are some harmonic problems in the city grid system that are caused by the passive diode rectifiers in the EVSEs. They recommended active rectification to enhance the charger waveforms [39].

Song Hui et al. studied the failures of the grid (voltage decreases, three-phase unbalanced voltage, harmonic and pollution, etc.) on the EVSE. The study showed that different types of rectifiers have different reactions against voltage distortion and the variable types of the voltage decreasing [40].

Haiyang Lin et al. studied the required charging power of the EVs in various locations. For the subject, four charging locations: residential, work, business, and recreation area and seven journey goals were generated to study the charging of the EVs [41].

\section{WIRELESS CHARGING}

The wireless charging system can be explained by the coupled Inductive Power Transfer (IPT) system. A Danish scientist, Hans Christian Oersted 
discovered that magnetic fields could be created by electric currents [42]. According to the Oersted discovery, Faraday invented a device, two insulated coils wrapped around an iron ring, one of the coils wrapped on a side of the ring and the other was wrapped on the opposite side. He then supplied electricity to one coil and observed that the current was induced in the other coil [43]. The event is called mutual induction. The relation of electricity and magnetism was mathematically formulated by James Clerk Maxwell as Faraday's law and Nicola Tesla achieved wireless electric transmission at long distances [44].

The electric power is converted into magnetic power by primer coils, then the secondary coil collects the generated electromagnetic field energy and it is transformed into the electric power, then EVs are charged. This event explains the main concept of transformers $[45,46]$. To avoid electrical damages, the coils have the same resonant frequency. By transmitting the current to batteries of the electric vehicle, the charging process is initiated. The inductive charging process has already been used for small electronic appliances (mobile phones, toothbrushes, etc.)

Due to the absence of electrical contacts, the transmitter and receiver of the IPT system are independent. This feature significantly increases the safety and reduces the possibility of vandalism [47].

Georgiy Babat developed the first application of the IPT system on the EV in 1943. The efficiency of the application was only $4 \%$ [48].

The first wireless charging technology was stationary; the system is also called the static inductive charging system. For charging EVs during transit, the dynamic wireless charging system was developed [49].

Srdjan Lukic and Zeljko Pantic studied the subject of static and dynamic wireless charging. They built a testbed for dynamic wireless charging [50].

Morimoto Minoshima and Yasuharu Odachi studied the failure scenarios of the wireless charging process and invented a system. If the EV is driven away from the primary coil during the charging process, damages can happen to either or both of the coils. For avoiding the accident between the coils even when the vehicle is moved inadvertently in a direction, the higher coil has a bent portion providing a path through which the other coil moves without colliding [51].
The first commercialized IPT system for public transportation was implemented by Wampfler AG [52]. The Wampfler system operates at $15 \mathrm{kHz}$ frequency and $80 \mathrm{~A}$ rated current, $30 \mathrm{~kW}$ transmitting rated power and $4 \mathrm{~cm}$ air gap between the system and the electric buses.

The Unplugged Project proposed a static inductive charging for safety and economic feasibility. The Project performed with about $90 \%$ efficiency. The main challenge of the project is the perfect alignment of the transmitter and receiver systems [53].

Tests of Shijo et al. implemented a standardized $88 \mathrm{kHz}$ frequency band for charging electric buses [54]. When $50 \mathrm{~kW}$ electric power is transmitted from the primer coils, $44 \mathrm{~kW}$ electric power is measured on the battery side of the electric vehicle. For reducing emissions within limits of radio law, a two-channel inverse phase wireless power transfer system and low-pass filter are designed. The electric circuit can be seen in Figure 8 .

Chwei-Sen Wang et al. studied the charging of electric vehicles on the move by the principle of inductive charging [55]. In the study, the electric circuit of the secondary coils operates on the resonant frequency to provide maximum power transfer. For control of the transmitted power, the frequency of the primer coils should be adjusted by secondary coils. However, due to diverse frequencies of different vehicles, the secondary coil frequency cannot be indicated accurately; thus, the efficiency of the wireless power transfer system is limited. Alternative switching mode can be designed to control the transmitted power. The disadvantage of this method are the losses of switching. For this study, a circuit is designed with $30 \mathrm{~kW}, 45 \mathrm{~mm}$ air gap, $20 \mathrm{kHz}$ rated frequency and $150 \mathrm{~A}$ primer current.

Figure 9 shows the electric circuit which was designed by Chwei-Sen Wang et al. Primer and secondary coils are both compensated by using parallel capacitors. The parallel capacitor on the secondary coil $\left(C_{s}\right)$ has convenient current characteristics for charging the batteries; the parallel capacitor on primer coil $\left(C_{p}\right)$ produces a wide range current. For regulating the inverter current, a serial wound $L_{r}$ coil is added to the circuit [55].

Hanspeter Widmer et al. invented an apparatus for antenna alignment on a wireless charging system. The receiver and transmitter systems should be as close as possible to reduce the power loss on the 


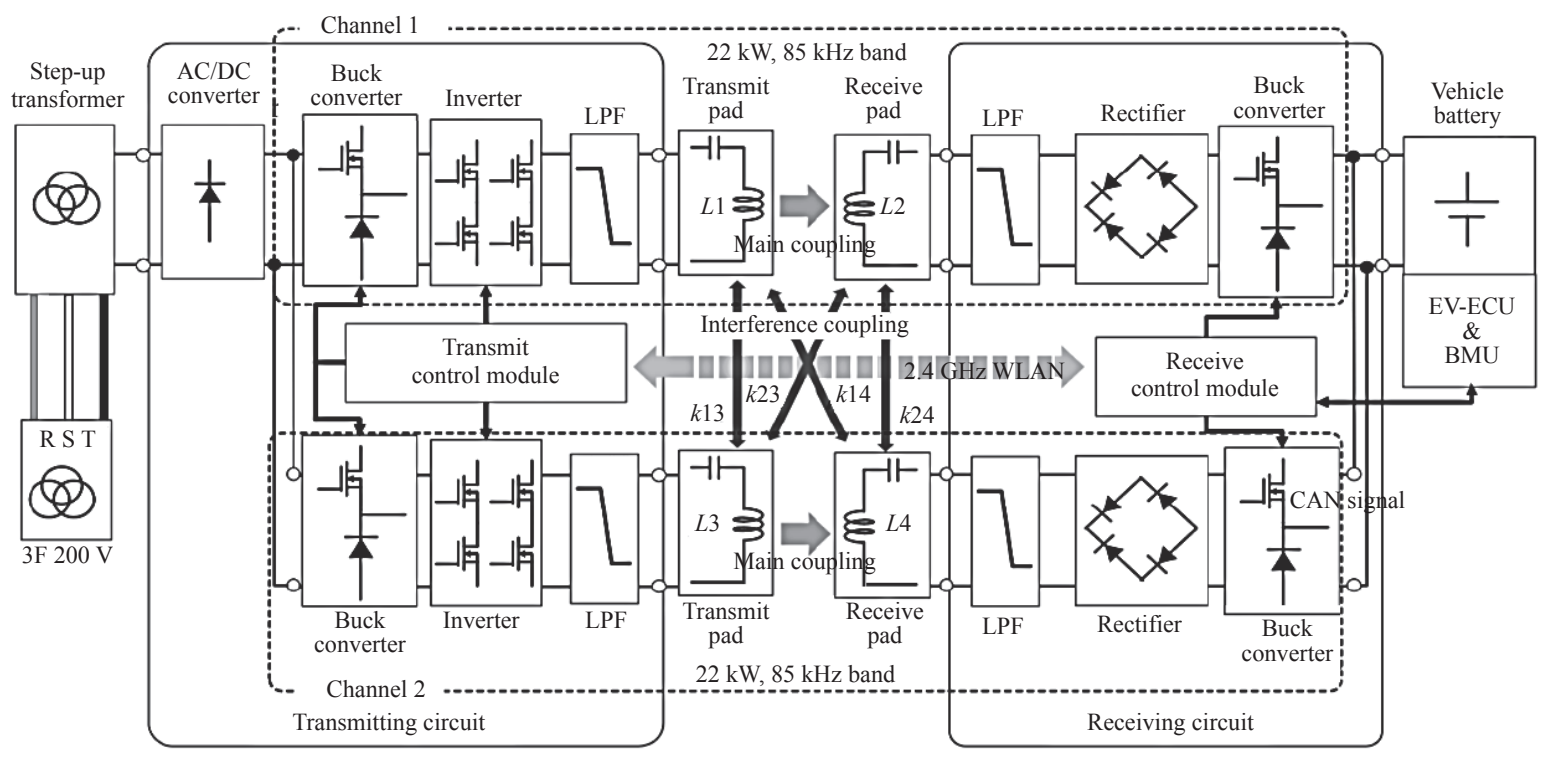

Figure 8 - Two channels inverse phase wireless power transfer system for charging EVS [54]

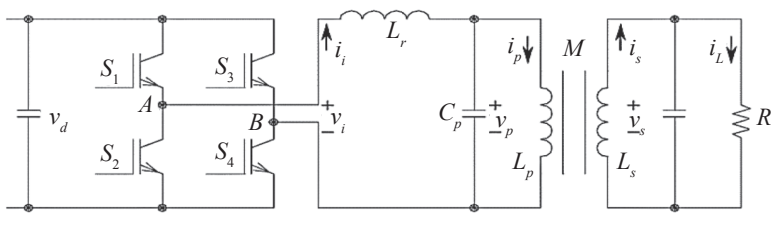

Figure 9 - Inductive charging circuit [55]

IPT system. The invented system includes a sensor for detecting the strength of the electromagnetic field in multiple dimensions [56].

Reza Tavakoli et al. studied the LCC resonant tank on the secondary circuit for wireless charging [57]. Owing to the LCC resonant filter, the small impedance which is produced by the reactive components on the filter can be observed on the primer coil. The present current should be controlled since the transmitted power is affected by the electric current. For the control, the current PI controller is designed. The controller should also limit the transmitted power. A forward fed additional controller is designed for this purpose. Primer coils would be powered until the vehicle reach higher efficiency. Because vehicles do this fast, primer coils should be powered on short-term like milliseconds. By adjusting the phase shift angle of transistors, the square wave width of the output of the inverter can be controlled.

Figure 10 shows the LLC resonant (compensator) circuit. The LCC tank filter to the output current of the inverter efficiently allows only fundamental harmonics passage from the primer coils. The compensator circuit input is the output of the phase shift angle controlled inverter. In Figure 10, VBf represents the fundamental harmonic voltages of output inverter.

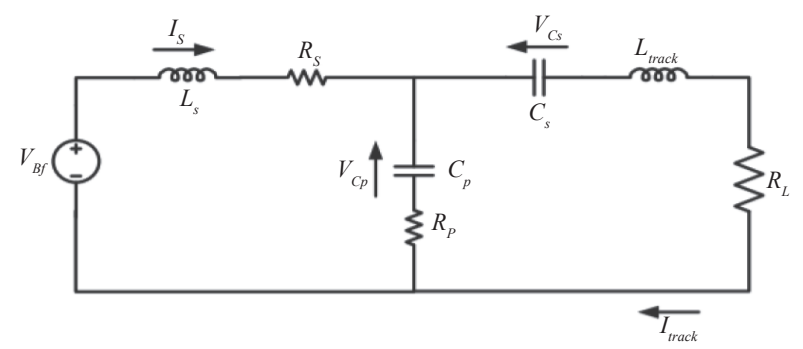

Figure 10-LCC resonant tank circuit [57]

\section{Wireless charging communication}

In an IPT system, it is vital to exchange information between the charger side and the EV side to give feedback. The communication can be divided into whether the signal is modulated on the power lines or if it applies a separate frequency band [58].

Leandros A. Maglaras et al. studied the dynamic wireless charging system. They announced Mobile Energy Disseminators (MEDs), a new process that can make it possible for EVs to extend their driving range in the city. The project uses inter-vehicle communications. Particular nodes, like commercial vehicles, can perform as energy sources to EVs. MEDs use the IPT system to charge the starving EVs [59].

An open interface standard for low power IPT system was developed by the Wireless Power Consortium (WPC). The consortium used the logo "Qi", thus the standard is also called the Qi Standard. 


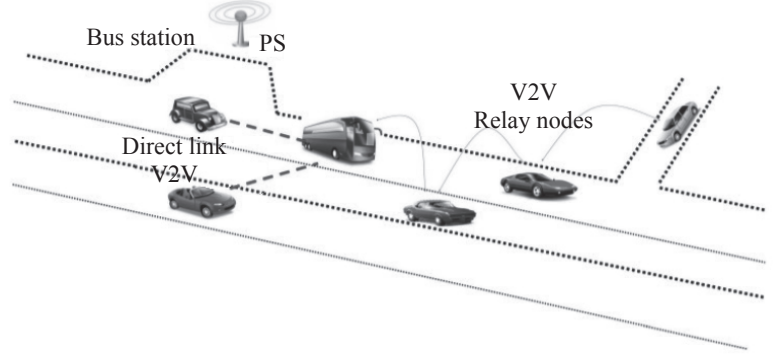

Figure $11-V 2$ (Vehicle to Vehicle) communication between $M E D$ and EV [59]

Since the receiver circuit should inform its required power to the transmitter, the communication standard is developed [60].

The electrical circuit of the receiver can be seen in Figure 12. The communication between the receiver and the transmitter is performed by load modulation. The communication is adjusted by switching a small capacitive load $\left(C_{c m}\right)$ in the receiver [60]. The $2 \mathrm{kHz}$ signal is modulated in the Qi standard onto the power carrier frequency [58].

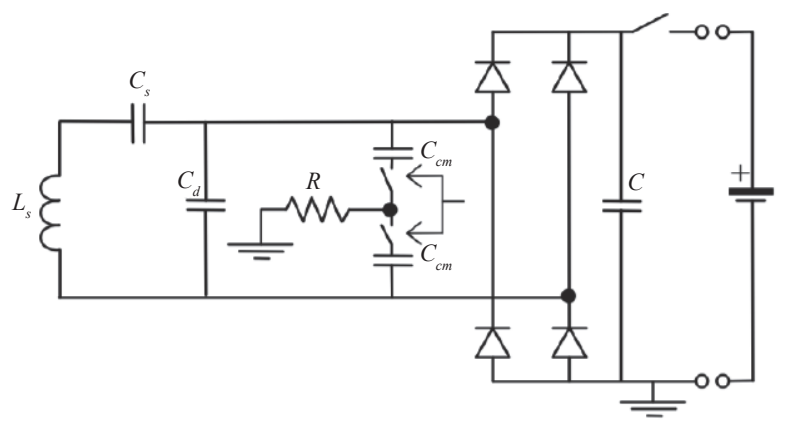

Figure 12 - Electrical diagram of a receiver [60]

Dedicated Short-Range Communication (DSRC) is used for the EV prototype in Oak Ridge National Laboratory (ORNL). The DSRC is based on IEEE 802.11p Wireless Fidelity (Wi-Fi) [58].

Allon Echols et al. discussed and compared two implementations, the one based on Wi-Fi and the other on DSRC technologies. RFID and DSRC communication systems are precise and reliable. However, due to latency issues, many of these communication protocols cannot be used for an IPTG system [61]. According to the Technical Information Report, Wi-Fi, DSRC or RFID systems are proposed [62].

Andrea Gil et al. studied the appropriate communication methods for IPT systems. According to the results, low-rate wireless Personal Area Network (PAN) equipment like ZigBee may be used for stationary IPT systems [63]. However, traditional communication PANs are insufficient for dynamic IPT because of the range.

Table 2 compares wireless technologies used by Communication Access for Land Mobiles (CALM). Satellite has the best coverage feature. However, it is inappropriate for IPT charging because of the latency issue. The same latency problem can be observed in FM radio and WiMAX [63].

\section{Safety and regulations of wireless charging}

All technologies in wireless charging are expected to be appreciated by the market if the safety for humans cannot be resolved. All devices have to conform to safety standards. The "Standard for Safety Levels with Respect to Human Exposure to Radio Frequency Electromagnetic Fields, $3 \mathrm{kHz}$ to $300 \mathrm{GHz}$ " is published by the Institute of Electrical and Electronics Engineers (IEEE) [64]. The "Guidelines for limiting exposure to time-varying electric, magnetic, and electromagnetic fields (up to $300 \mathrm{GHz}$ )" is published by the International Commission on Non-Ionizing Radiation Protection (ICNIRP) [65]. These standards are developed to avoid any faults. ICNIRP has announced that there is no obvious evidence that electromagnetic fields cause cancer. However, there are other negative effects such as tissue heating, nerve, and muscle stimulation [66]. The standards show that tissue heating is set at 1 degree Celsius at a specific absorption rate (SAR) of $0.008 \mathrm{~W} / \mathrm{kg}$ for a long-term exposure and $4 \mathrm{~W} / \mathrm{kg}$ for a short-term exposure. When EVs are charged by the IPT system, a low kilohertz range should be used (roughly from $10 \mathrm{kHz}$ to $100 \mathrm{kHz}$ ) due to electromagnetic compatibility and power efficiency. Ding et al. studied the exposure of a person in the near-field of a wireless inductive charging

Table 2 - Assessment of wireless communication technologies [63]

\begin{tabular}{|l|c|c|c|c|c||}
\hline & DSRC & Fm Radio & Cellular & WiMAX & Satellite \\
\hline \hline Max $[\mathrm{km}]$ & $<1$ & Hundreds & $<10$ & $<50$ & Thousands \\
\hline Data rate $[\mathrm{Mbps}]$ & $3-27$ & $>10 \mathrm{kbps}$ & 100 & 70 & $100-$ \\
\hline Latency (average) & Very low & High & Low & High & Very high \\
\hline Mobile connectivity & Low & Low & Very high & High & Very high \\
\hline
\end{tabular}


system. They modelled the human body using MATLAB-based meshed generating toolbox Iso2mesh. They found that the induced electromagnetic fields in the near-field exposure scenarios completely comply with the safety guidelines [67].

\section{POWER ELECTRONIC SYSTEMS}

The power electronic circuits of the EV charging systems are performed by an $\mathrm{AC} / \mathrm{DC}$ rectifier and a $\mathrm{DC} / \mathrm{DC}$ converter [68]. This topology is valid for all types of charging methods (plug-in charging, pantograph charging, and even wireless charging). According to IEC 15118-2:3 standards, the output voltage of EVSE must be controlled [35, 41]. During the pre-charging state of EVSE, the electric vehicle receives less than $2 \mathrm{~A}$ current and a certain voltage. If the voltage difference between the electric vehicle and EVSE is less than $20 \mathrm{~V}$, the charging process can be initiated. At the beginning of the charging process, EVSE checks the isolation of the high voltage system and it keeps reporting this value during the whole charging time [19]. The electric power is received from the grid by the rectifier and it is carried to the DC/DC converter [15]. The DC high voltage can be produced by 3-phase AC. The DC power is connected to a filter after being converted by 3-phase rectifiers; the output of the filter is connected to a DC/DC converter and finally passed through another filter to the vehicle battery [40].
According to the required characteristics of the systems, the AC/DC circuit may be performed in different topologies [68].

\section{1 $\mathrm{AC} / \mathrm{DC}$ rectifier}

In the rectification stage, $\mathrm{AC}$ power is converted to DC so that the EV can be charged. The converting process is performed by $\mathrm{AC} / \mathrm{DC}$ rectifiers. Vitor Monteiro et al. investigated the EV charging systems according to unidirectional power flow and bi-directional power flow [68]. Figure 13 shows the main AC-DC power converter topologies.

Song Hui divided the rectifiers into three main groups which are mentioned below [40].

Figure 14 demonstrates the electric circuits of the rectifiers. Despite the formation of many harmonics, the uncontrolled rectifiers are small-size and low-cost. It is simple to realize, and cheap to construct. Due to the input current, the waveform is not sinusoidal, electrical grid power quality is degraded [68].

Twelve pulse rectifiers are designed by a serial or parallel connection of two transformers. Figure 14 (middle) shows the twelve-pulse rectifier. When the high-current output is required, the parallel rectifier connection is used; and when high voltage output is required, the serial rectifier connection is used.

Figure 14 (bottom) shows a controlled rectifier electric circuit. The PWM-controlled rectifier can be produced by using IGBT and MOSFET.
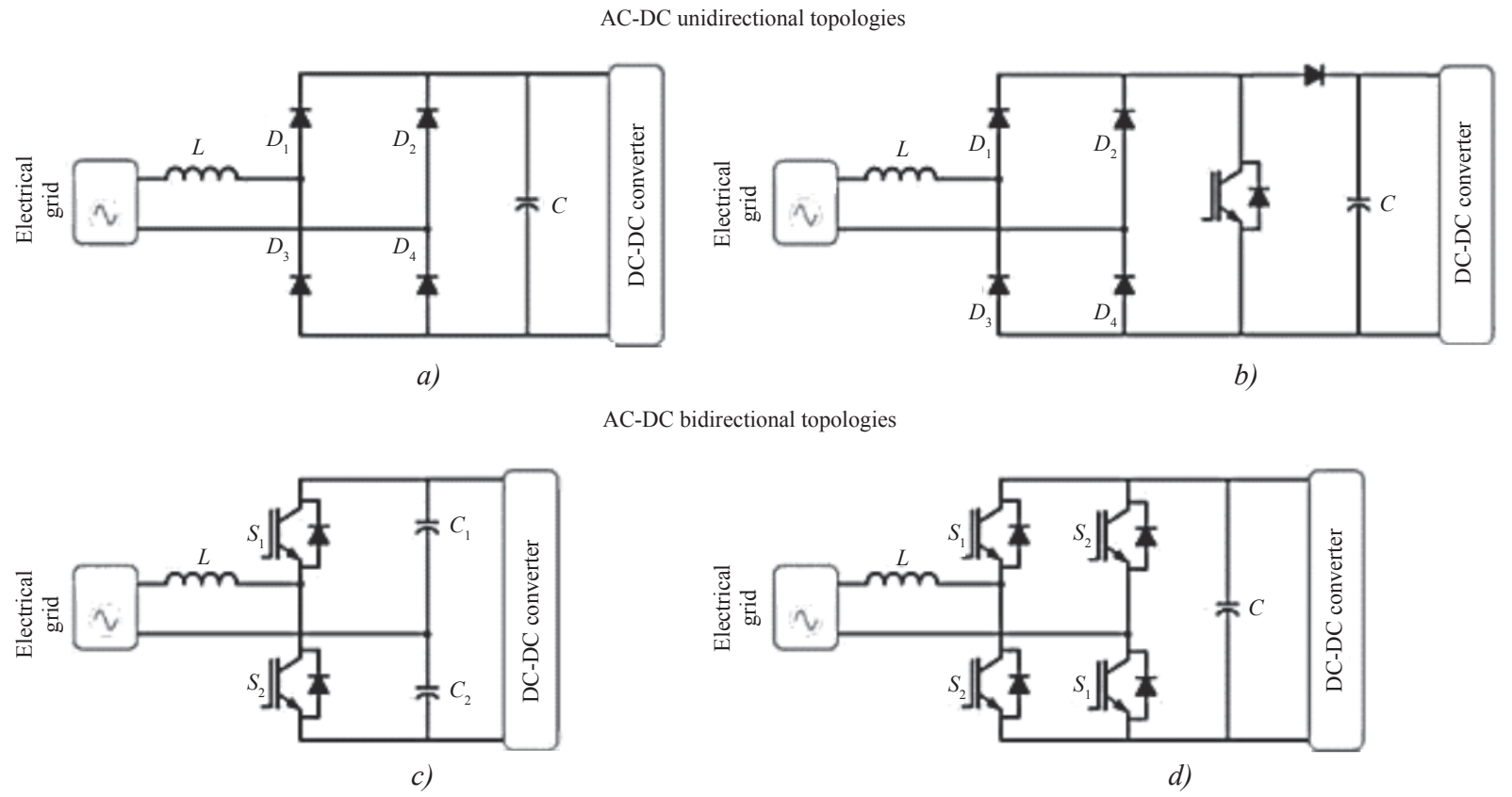

Figure $13-A C-D C$ rectifier topologies used in EVSE [68] 

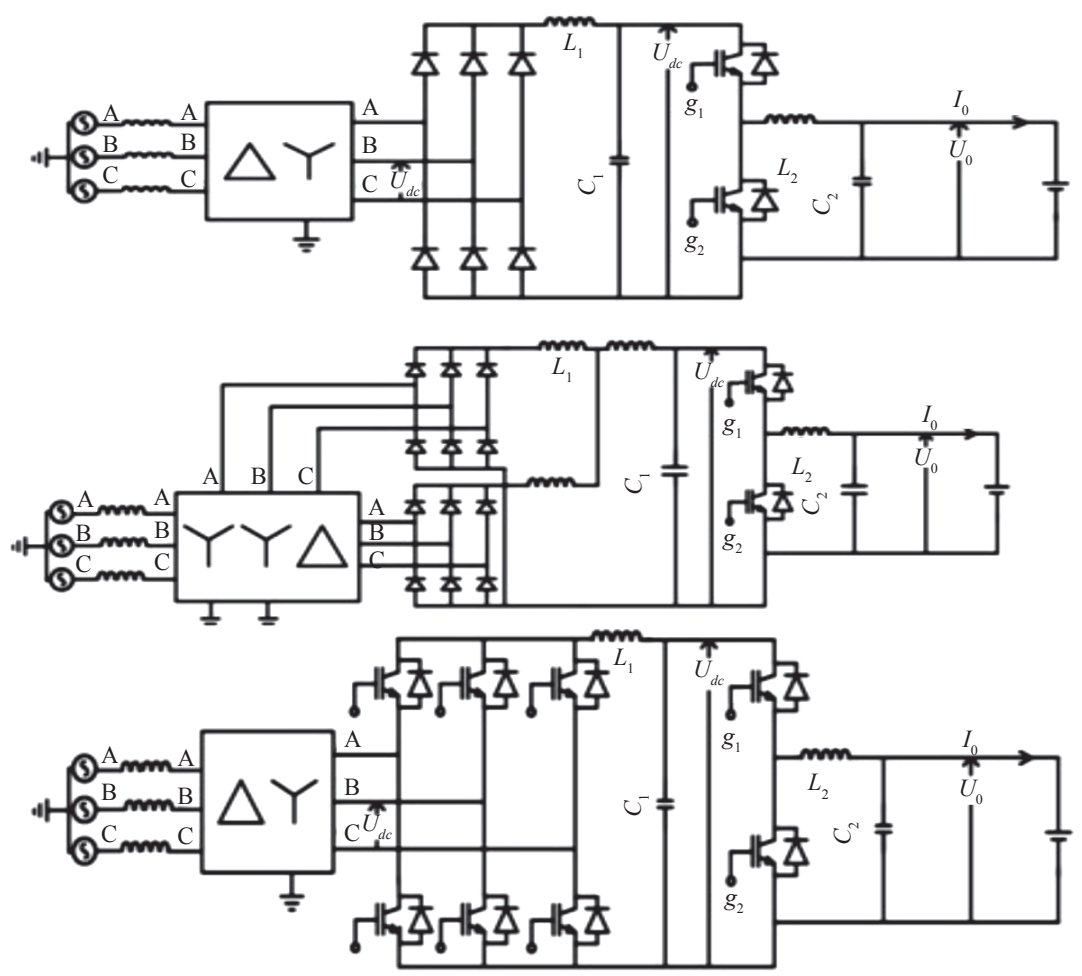

Figure 14 - Uncontrolled rectifier (top), twelve-pulse rectifier (middle), PWM-controlled rectifier (bottom) [40]

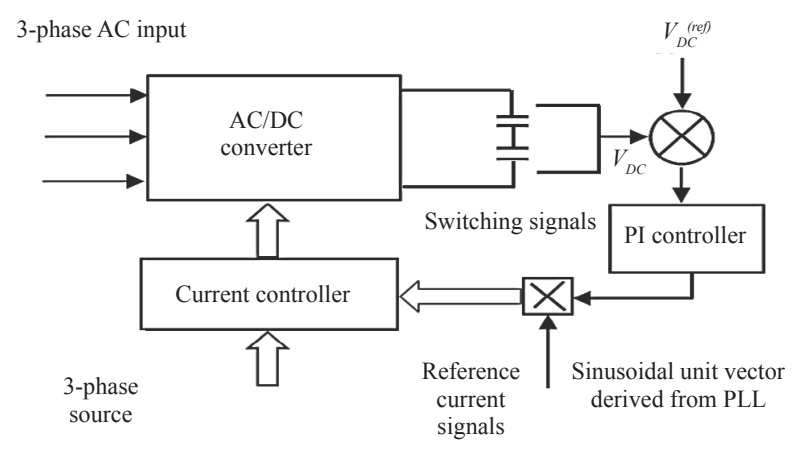

Figure 15 - Control loop for the rectifier

Depending on the power of the circuit, the choice between these two semiconductor components is made. Generally, IGBT is used on high-power demanded circuits. Compared with an uncontrolled rectifier and twelve-pulse rectifier, the PWM-controlled rectifier controls the output voltage of the rectifier via pulse signal which is applied to the gate pin of IGBT. The PWM-controlled rectifiers generate fewer harmonics, high-power factor, and constant DC voltage but it is expensive.

For the appropriate operation of the rectifier, the generated DC voltage should be higher than the AC peak voltage at any time. Soodeh Negarestani et al. used a PI controller for achieving constant DC voltage. The sinusoidal unit vector is modulated with the output of the controller and the unit vector generated by the Phase Locked Loop (PLL). Thus, the required current can be generated for every phase. Figure 15 illustrates the control loop. The method provides a fast response and reduces the steadystate error [29].

\subsection{DC/DC converter}

DC/DC converters provide a wide charging range for batteries of electric vehicles [69]. Figure 16 illustrates the main DC-DC power converter topologies in the EVSE.

Vishnu Mahadeva Iyer et al. used Dual Active Bridge (DAB) for DC to DC converter [69]. DAB converter circuit and rectifier are illustrated in Figure 17. The DAB converter can provide bidirectional energy flow and galvanic isolation between the grid and the battery. These converters can perform the same, regardless of the soft switching and power flow direction. Thanks to DAB converters, EVSE can be used on the application of Vehicle to Grid (V2G).

Wang Xunto et al. used the LLC circuit for duplex energy flow on DC/DC converter [70]. LLC converter has fewer switching elements than $\mathrm{DAB}$ converter but forward and backward behaviours of the LLC converter are different from each other. 


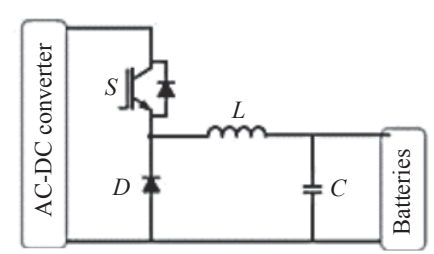

a)

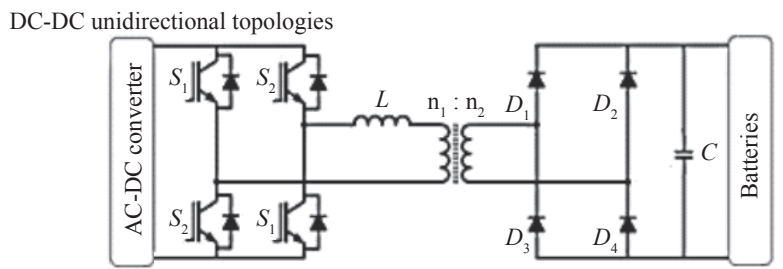

b)

DC-DC bidirectional topologies
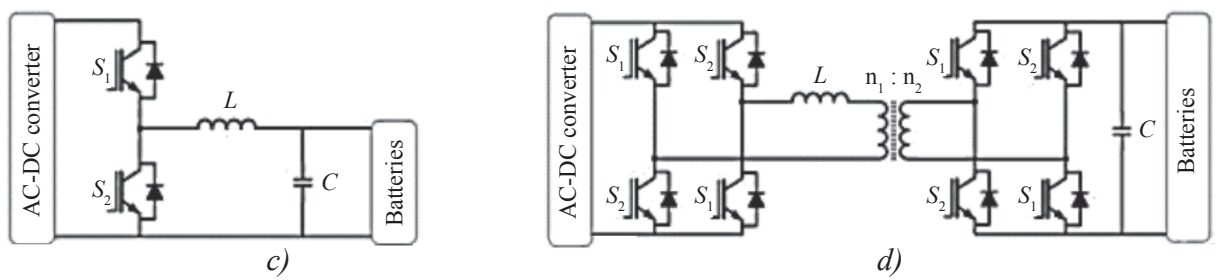

d)

Figure 16-DC/DC converter topologies [68]

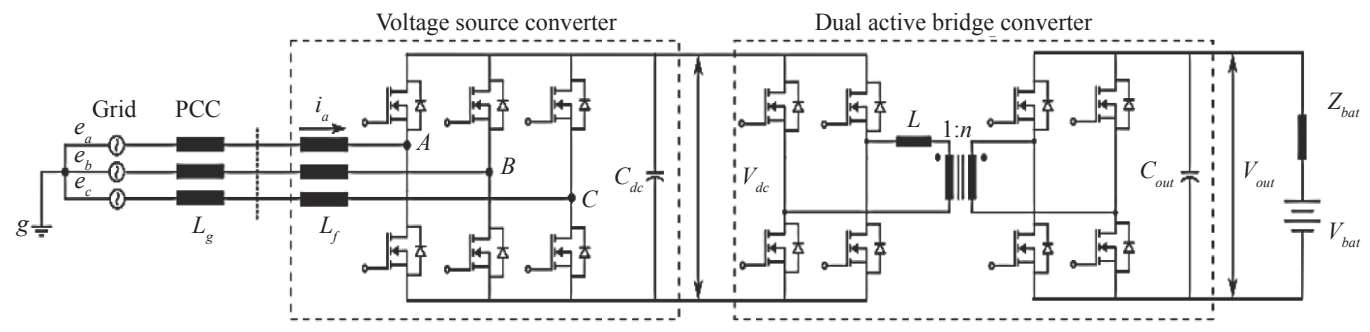

Figure 17 - Power circuit of DAB converter EVSE [69]
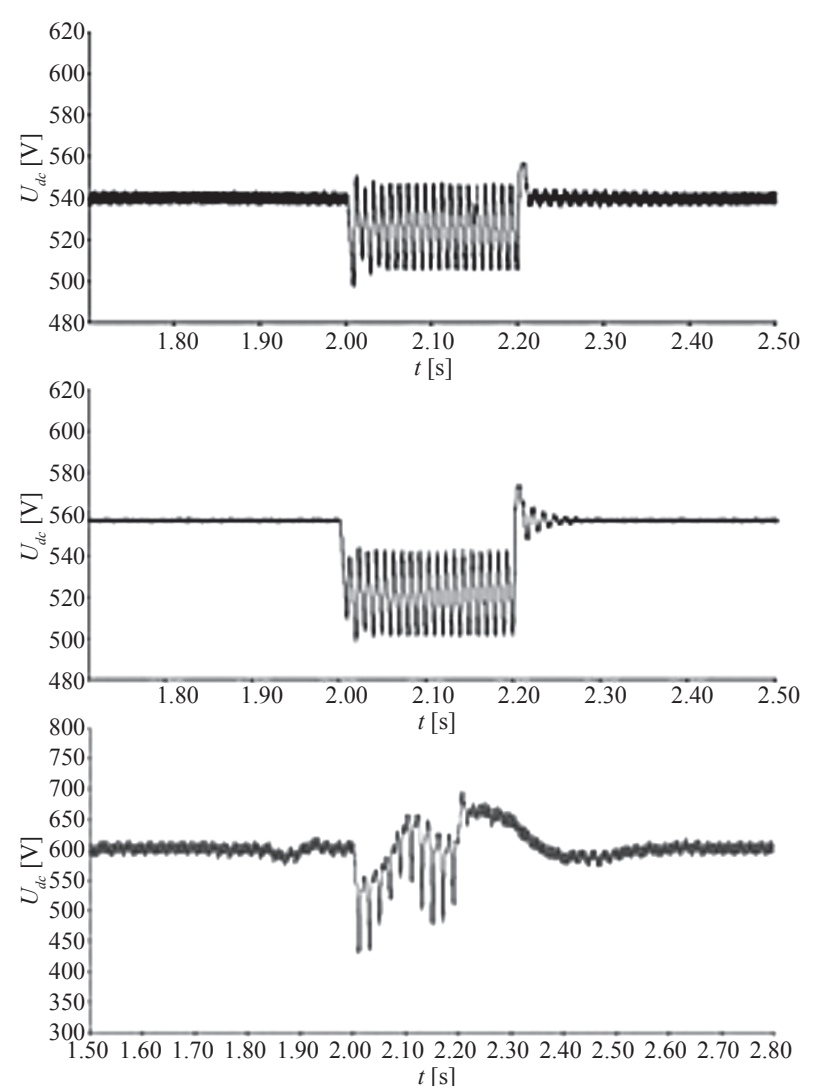

Figure 18 - Effects of single-phase short circuit on uncontrolled rectifier (top), twelve-pulse rectifier (middle), PWM-controlled rectifier (bottom) [40]
Therefore, it is hard to get an LLC converter that performs well in all operating modes. Compared with the DAB converter, LLC resonant tank converter has fewer switching elements [69].

The results for the single-phase short circuit of each of the AC/DC rectifiers are given are given in Figure 18 [40]. The results shown in Figure 18 illustrate the fluctuation due to the short circuits of the single phase of the uncontrolled rectifier (top), twelve-pulse rectifier (middle) and PWM controlled rectifier (bottom) in Figure 14. Fluctuations in the short circuit are not too large to prevent the charging process. In the twelve-pulse rectifier, the output voltage fluctuated more than the six-pulse uncontrolled rectifier. If the input voltage of the PWM-controlled rectifier is less than a definite value, a sudden drop in voltage occurs at the output. It is preferred to use 6-or 12-pulse uncontrolled rectifiers if there are large voltage distortions. If small voltage distortions are present, the PWM-controlled rectifiers are preferred [40].

\section{CONCLUSION}

This study focuses on the methods of charging electric buses. The research on the charging process mentioned in two different groups and a general perspective have been established. Mode 4 
discusses the conductive charging process. The paper presents the effects of EVSE on the grid and vice versa, the effects of semiconductors and inverter types on the efficiency of EVSE, the performance of the communication channel. In addition to these studies, supplementary explanations are made for understanding the system. When the advantages and disadvantages are listed according to the purpose of different types of converters, it has been found that controlled $\mathrm{AC} / \mathrm{DC}$ rectifiers are recommended for the EVSE, and DC/DC bidirectional DAB converters are recommended for wide-range charging. Due to the harmonic effects of rectifiers to the grid, using LCL filter and to avoid the unstable operation of the filter, it is recommended that an additional resistor should be implemented on the power circuit of EVSE. It is also suitable to use the PLC signals from the PWM channel (control pilot) when the results of the operation for the communication channel are evaluated. According to IEC 15118, standard, PLC system is decided for the high-level communication protocol. In this way, a V2G energy transfer system can be used. It is also recommended to use PID controllers to avoid malfunction or failure in the system.

\section{Doç.Dr. UMIT KEMALETTIN TERZI ${ }^{1}$}

(Corresponding Author)

E-mail: terzi@marmara.edu.tr

Master Ogrencisi HUSEYIN ENES ILHAN ${ }^{2}$

E-mail: ilhanh19@itu.edu.tr

\section{Dr. HABIB KAYMAZ ${ }^{3}$}

E-mail: habib.kaymaz@daimler.com

Prof.Dr. HASAN ERDAL ${ }^{1}$

E-mail: herdal@marmara.edu.tr

Doç.Dr. HUSEYIN ÇALIK ${ }^{4}$

E-mail: hcalik@istanbul.edu.tr

${ }^{1}$ Marmara Üniversitesi, Teknoloji Fakültesi

Elektrik Elektronik Mühendisliği Bölümü

34722, Kadikoy /Istanbul, Türkiye

2 İTÜ Fen Bilimleri Enstitüsü,

Elektronik ve Haberleşme ABD

Ayazağa Kampusu, 34469 Maslak /Istanbul, Türkiye

${ }^{3}$ Mercedes Benz Türk AS, Otobüs Geliştirme

34519 Esenyurt /Istanbul, Türkiye

4 İstanbul Üniversitesi-Cerrahpaşa Teknik Bilimler Meslek

Yüksekokulu Büyükçekmece Yerleşkesi

34500, Büyükçekmece/İstanbul, Türkiye

\section{TICARI ELEKTRIKLI ARAÇ ŞARJ YÖNTEMLERININ INCELENMESI}

\section{ÖZET}

Elektrikli araçlar her geçen gün daha da yayginlaşmaktadır. Ilk icat edilen araçlardan birisi olan elektrikli araçlar, yeterli enerji depolama özelliği olmamast ve elektrikli motorların verimliliklerinin düşük olmasindan kaynaklı olarak uzun yıllar göz ardı edilmişstirler. Gelişen yarı iletken ve batarya teknolojisi bu araçlara olan yönelimi her geçen gün daha da arttırmaktadır. Fakat mevcut bataryaların kapasiteleri yeteri kadar büyük değildir. Araçların çok uzun olmayan menzillerde (yaklaşı $150 \mathrm{~km}$ ) tekrar şarj edilmeleri gerekmektedir. Bu sebeple elektrikli araçların normal otomobil olarak kullanilmasından daha çok, kalkış varış bilgileri bilinen şehir içi otobüslerinde kullanılmaları konusunda çalışılmaktadır. Doğru şarj teknolojisi ve elektrikli otobüsler için yenilenebilir enerji varlığ sayesinde şehirler daha az gürültü ve CO2 emisyonuna sahiptir. İçten yanmalı motorların enerji tüketimi, elektrik motorlarından daha yüksektir. Bu makalede, ticari elektrikli araç şarj yöntemleri ile ilgili çallş̧malar gözden geçirilecek ve plug-in şarj işlemleri ayrıntılı olarak açıklanacakttr. Bu çallşsma, elektrikli araç ve Elektrikli Araç Tedarik Ekipmanları (EVSE) arasında plug-in şarj işlemi iletişiminin nasıl yapıldı̆̆ına ilişskin soruları yanıtlamaya çalışmaktadır.

\section{ANAHTAR KELIMELER}

Elektrikli Otobüs; Ulaşım ve Toplum; Elektrikli Otobüsler için Şarj Yöntemleri; Elektrikli Araç Şarj Sistemlerinin Haberleşme Protokolleri; Güvenlik;

\section{REFERENCES}

[1] Georgievski B, Al Qudah A. The effect of the Volkswagen scandal (a comparative case study). Research Journal of Finance. 2016;7(2).

[2] Chan C, Wong Y. Electric vehicles charge forward. IEEE Power Energy Magazine. 2004;2(6): 24-33.

[3] Khaligh A, Li Z. Battery, ultracapacitor, fuel cell, and hybrid energy storage systems for electric, hybrid electric, fuel cell, and plug-in hybrid electric vehicles: State of the art. IEEE Transactions on Vehicular Technology. 2010;59(6): 2806-2814.

[4] European Environment Agency. Electric vehicles and the energy sector - impacts on Europe's future emissions. Available from: https://www.eea.europa.eu/themes/transport/electric-vehicles/electric-vehicles-and-energy/\#parent-fieldnametitle2016 [Accessed $7^{\text {th }}$ November 2019].

[5] Fernández RÁ. A more realistic approach to electric vehicle contribution to greenhouse gas emissions in the city. Journal of Cleaner Production. 2018;172: 949-959.

[6] Gil A, Sauras-Perez P, Taiber J. Communication requirements for dynamic wireless power transfer for battery electric vehicles. In: Proceedings of the 2014 IEEE International Electric Vehicle Conference (IEVC), 17-19 Dec. 2014, Florence, Italy. IEEE; 2014. p. 1-7.

[7] Simpson M, Markel T. Plug-in electric vehicle fast charge station operational analysis with integrated renewables. National Renewable Energy Lab. (NREL), Golden, CO (United States). Report No. NREL/CP5400-53914, 2012.

[8] International Organization for Standardization. ISO 15118-1:2013 - Vehicle to grid communication interface: General information and use-case definition. Switzerland: ISO; 2013.

[9] Yilmaz M, Krein PT. Review of battery charger topologies, charging power levels, and infrastructure for 
Terzi UK, Ilhan HE, Kaymaz H, Erdal H, Çalik H. A Review of Commercial Electric Vehicle Charging Methods

plug-in electric and hybrid vehicles. IEEE Transactions on Power Electronics. 2012;28(5): 2151-2169.

[10] International Electrotechnical Commission. IEC 621961:2014 - Plugs, socket-outlets, vehicle connectors and vehicle inlets - Conductive charging of electric vehicles: General requirements. Switzerland: IEC; 2014.

[11] Bansal P. Charging of electric vehicles: technology and policy implications. Journal of Science Policy Governance. 2015;6(1): 1-20.

[12] Society of Automobile Engineers. J1772:2010 - Electric Vehicle and Plug-in Hybrid Electric Vehicle Conductive Charge Coupler. USA: SAE; 2010.

[13] Mouli GRC, Kaptein J, Bauer P, Zeman M. Implementation of Dynamic Charging and V2G Using Chademo and CCS/Combo DC Charging Standard. In: Proceedings of the 2016 IEEE Transportation Electrification Conference and Expo (ITEC), 27-29 June 2016, Dearborn, MI, USA. IEEE; 2016. p. 1-6.

[14] The Institute of Electrical and Electronics Engineers. 2030.1.1-2015:2016 - IEEE Standard Technical Specifications of a DC Quick Charger for Use with Electric Vehicles. IEEE; 2016.

[15] Aziz M, Oda T. Simultaneous quick-charging system for electric vehicle. Energy Procedia. 2017;142: 1811-1816. Available from: doi:10.1016/j.egypro.2017.12.568

[16] Osawa K. Combined charging inlet. US 9,352,660 B2 (Patent), 2016.

[17] HomePlug Powerline Alliance. Home Plug Green PHY The Standard For In-Home Smart Grid Powerline Communications. Available from: https://www.codico.com/ fxdata/codico/prod/media/Datenblaetter/AKT/HomePlug_Green_PHY_whitepaper_100614[1].pdf[Accessed $7^{\text {th }}$ November 2019].

[18] International Electrotechnical Commission. IEC 62763:2013 - Pilot function through a control pilot circuit using PWM (pulse width modulation) and a control pilot wire. Switzerland: IEC; 2013.

[19] Initiative Charging Interface. Design Guide for Combined Charging System. Available from: http://tesla.o.auroraobjects.eu/Design_Guide_Combined_Charging System_V3_1_1.pdf [Accessed $7^{\text {th }}$ November 2019].

[20] Mannah M, Batard C, Ginot N, Machmoun M. Power line communication over feeder cables in an industrial environment. In: Proceedings of the 2009 IEEE International Symposium on Power Line Communications and Its Applications, 29 Mar- 1 Apr 2009, Dresden, Germany. IEEE; 2009. p. 255-260.

[21] Lewandowski C, Gröning S, Schmutzler J, Wietfeld C. Performance evaluation of PLC over the IEC 61851 control pilot signal. In: $5^{\text {th }}$ Workshop on Power Line Communications, Sep 2011, Arnhem, The Netherlands; 2011.

[22] Lewandowski C, Gröning S, Schmutzler J, Wietfeld C. Interference analyses of Electric Vehicle charging using PLC on the Control Pilot. In: Proceedings of the 2012 IEEE International Symposium on Power Line Communications and Its Applications, 27-30 March 2012, Beijing, China. IEEE; 2012. p. 350-355.

[23] International Organization for Standardization. ISO 15118-3:2015 - Road vehicles - Vehicle to grid communication interface: Physical and data link layer requirements. Switzerland: ISO; 2015.
[24] Zhang Y-H, Lin S-X, Chen L-B, Chang W-J, Hu W-W, Tang J-J, et al. An implementation of an in-vehicle power line communication system. In: Proceedings of the 2017 IEEE $6^{\text {th }}$ Global Conference on Consumer Electronics (GCCE), Nagoya, Japan. IEEE; 2017. p. 1-2.

[25] International Organization for Standardization. ISO 15765-4:2016 - Road vehicles - Diagnostic communication over Controller Area Network (DoCAN): Requirements for emissions-related systems. Switzerland: ISO; 2016.

[26] Antoniali M, Tonello AM, Lenardon M, Qualizza A. Measurements and analysis of PLC channels in a cruise ship. In: Proceedings of the 2011 IEEE International Symposium on Power Line Communications and Its Applications, 3-6 April 2011, Udine, Italy. IEEE; 2011. p. 102-107.

[27] Rhee J-G, Rhee E, Park J-S. Electromagnetic interferences caused by power line communications in the HF bands. In: Proceedings of the 2008 IEEE International Symposium on Power Line Communications and Its Applications, 2-4 April 2008, Jeju City, South Korea. IEEE; 2008. p. 249-252.

[28] Park C-U, Lee J-J, Oh S-K, Bae J-M, Seo J-K. Study and field test of power line communication for an electric-vehicle charging system. In: Proceedings of the 2012 IEEE International Symposium on Power Line Communications and Its Applications, 27-30 March 2012, Beijing, China. IEEE; 2012. p. 344-349.

[29] Negarestani S, Fotuhi-Firuzabad M, Rastegar M, Rajabi-Ghahnavieh A. Optimal sizing of storage system in a fast charging station for plug-in hybrid electric vehicles. IEEE Transactions on Transportation Electrification. 2016;2(4): 443-453.

[30] Steen D, Le AT. Fast charging of electric buses in distribution systems. In: Proceedings of the 2017 IEEE Manchester PowerTech., 18-22 June 2017, Manchester, UK. IEEE; 2017. p. 1-6.

[31] Prohaska R, Kelly K, Eudy L. Fast charge battery electric transit bus in-use fleet evaluation. In: Proceedings of the 2016 IEEE transportation electrification conference and expo (ITEC), 27-29 June 2016, Dearborn, Michigan, USA. IEEE; 2016. p. 1-6.

[32] Gong Z, Liang Q, Hua L, Miao XL, Heng J. City electric bus powered by ultracapacitors. US 8,564,253 B2 (Patent), 2013.

[33] Morrissey P, Weldon P, O’Mahony M. Future standard and fast charging infrastructure planning: An analysis of electric vehicle charging behaviour. Energy Policy. 2016;89: 257-270.

[34] Arancibia A, Strunz K. Modeling of an electric vehicle charging station for fast DC charging. In: Proceedings of the 2012 IEEE International Electric Vehicle Conference, 4-8 March 2012, Greenville, SC, USA. IEEE; 2012. p. 1-6.

[35] Naveen G, Yip TH-T, Xie Y. 2014 6th IEEE Power India International Conference (PIICON). In: IEEE Modeling and protection of electric vehicle charging station, 5-7 December 2014, Delhi, India. IEEE; 2014. p. 1-6..

[36] Paul TK, Aisu H. Management of quick charging of electric vehicles using power from grid and storage batteries. In: Proceedings of the 2012 IEEE International Electric 
Vehicle Conference, 4-8 March 2012, Greenville, SC, USA. IEEE; 2012. p. 1-8.

[37] Shao S, Pipattanasomporn M, Rahman S. Challenges of PHEV penetration to the residential distribution network. In: Proceeding of the 2009 IEEE Power \& Energy Society General Meeting, 26-30 July 2009, Calgary, AB, Canada. IEEE; 2009. p. 1-8.

[38] Bosovic A, Music M, Sadovic S. Analysis of the impacts of plug-in electric vehicle charging on the part of a real low voltage distribution network. In: Proceedings of the 2015 IEEE Eindhoven PowerTech., 29 June-2 July 2015, Eindhoven, The Netherlands. IEEE; 2015. p. 1-5.

[39] Thiringer T, Haghbin S. Quality Issues of a Battery Fast Charging Station for a Fully-Electric Public Transport System in Gothenburg City. Batteries. 2015;1(1): 22-33. Available from: doi:10.3390/batteries 1010022

[40] Hui S, Yonghai X. Study on the impact of voltage sags on different types of electric vehicle chargers. In: Proceedings of the 2016 China International Conference on Electricity Distribution (CICED), 10-13 Aug 2016, Xi'an, China. IEEE; 2016. p. 1-4.

[41] Lin H, Fu K, Liu Y, Sun Q, Wennersten R. Modeling charging demand of electric vehicles in multi-locations using agent-based method. Energy Procedia. 2018;152: 599-605. Available from: doi:10.1016/j.egypro.2018.09.217

[42] Ørsted HC. Selected Scientific Works of Hans Christian Ørsted. USA: Princeton University Press; 2014.

[43] Faraday M. V. Experimental researches in electricity. Philosophical transactions of the Royal Society of London. 1832;(122): 125-162. Available from: doi: 10.1098/ rstl.1832.0006

[44] Tesla N. The transmission of electrical energy without wires as a means for furthering peace. Electrical World Engineer. 1905;1: 21-24.

[45] Gnann T, Funke S, Jakobsson N, Plötz P, Sprei F, Bennehag A. Fast charging infrastructure for electric vehicles: Today's situation and future needs. Transportation Research Part D: Transport and Environment. 2018;62: 314-329.

[46] McLyman CWT. Transformer and inductor design handbook. UK: CRC press; 2016.

[47] Cirimele V, Diana M, Freschi F, Mitolo M. Inductive power transfer for automotive applications: State-of-theart and future trends. IEEE Transactions on Industry Applications. 2018;54(5): 4069-4079.

[48] Babat GI. Electrodeless discharges and some allied problems. Journal of the Institution of Electrical Engineers-Part III: Radio and Communication Engineering. 1947;94(27): 27-37.

[49] Jang YJ. Survey of the operation and system study on wireless charging electric vehicle systems. Transportation Research Part C: Emerging Technologies. 2018;95: 844-866.

[50] Lukic S, Pantic Z. Cutting the cord: Static and dynamic inductive wireless charging of electric vehicles. IEEE Electrification Magazine. 2013;1(1): 57-64.

[51] Minoshima N, Odachi Y. Inductive coupler for electric vehicle charger. 5,703,461 (Patent), 1997.

[52] Boys JT, Green AW. Inductive power pick-up coils. 5,528,113 (Patent), 1996.
[53] Sanz J, Villa J, Sallan J, Perie J, Duarte LG. UNPLUGGED project: Development of a $50 \mathrm{~kW}$ inductive electric vehicle battery charge system. In: Proceedings of the 2013 World Electric Vehicle Symposium and Exhibition (EVS27), 17-20 Nov. 2013, Barcelona, Spain. IEEE; 2013. p. 1-7.

[54] Shijo T, Ogawa K, Moritsuka F, Suzuki M, Ishihara H, Kanekiyo Y, et al. $85 \mathrm{kHz}$ band $44 \mathrm{~kW}$ wireless power transfer system for rapid contactless charging of electric bus. In: Proceedings of the 2016 International Symposium on Antennas and Propagation (ISAP), 24-28 Oct. 2016, Okinawa, Japan. IEEE; 2016. p. 38-39.

[55] Wang C-S, Stielau OH, Covic G. Design considerations for a contactless electric vehicle battery charger. IEEE Transactions. 2005;52(5): 1308-1314.

[56] Widmer H, Sieber L, Cook NP. Antenna alignment and vehicle guidance for wireless charging of electric vehicles. US 2012/0262002 A1 (Patent), 2012.

[57] Tavakoli R, Jovicic A, Chandrappa N, Bohm R, Pantic $Z$. Design of a dual-loop controller for in-motion wireless charging of an electric bus. In: Proceedings of the 2016 IEEE Energy Conversion Congress and Exposition (ECCE), 18-22 Sep. 2016, Milwaukee, WI, USA. IEEE; 2016. p. 1-8.

[58] Li S, Mi CC. Wireless power transfer for electric vehicle applications. IEEE Journal of Emerging and Selected Topics in Power Electronics. 2014;3(1): 4-17.

[59] Moschoyiannis S, Maglaras L, Jiang J, Topalis F, Maglaras A. Dynamic wireless charging of electric vehicles on the move with mobile energy disseminators. International Journal of Advanced Computer Science and Applications (IJACSA). 2015;6(6): 239-251.

[60] Van Wageningen D, Staring T. The Qi wireless power standard. In: Proceedings of the $14^{\text {th }}$ International Power Electronics and Motion Control Conference EPE-PEMC, 6-8 Sep. 2010, Ohrid, Macedonia. IEEE; 2010. p. 15-25.

[61] Azad AN, Echols A, Kulyukin VA, Zane R, Pantic Z. Analysis, Optimization, and Demonstration of a Vehicular Detection System Intended for Dynamic Wireless Charging Applications. IEEE Transactions on Transportation Electrification. 2018;5(1): 147-161.

[62] Society of Automotive Engineers. J2954 - Wireless Power Transfer for Light-Duty Plug-In: Electric Vehicles and Alignment Methodology. SAE; 2016.

[63] Gil A, Sauras-Perez P, Taiber J. Communication requirements for dynamic wireless power transfer for battery electric vehicles. In: Proceedings of the 2014 IEEE International Electric Vehicle Conference (IEVC), 17-19 Dec. 2014, Florence, Italy. IEEE; 2014. p. 1-7.

[64] The Institute of Electrical and Electronics Engineers. C95.1a-2010 - IEEE Standard for Safety Levels with Respect to Human Exposure to Radio Frequency Electromagnetic Fields, $3 \mathrm{kHz}$ to $300 \mathrm{GHz}$. USA: IEEE; 2010.

[65] ICNIRP. Guidelines for limiting exposure to time-varying electric, magnetic, and electromagnetic fields (up to $300 \mathrm{GHz}$ ). Health phys. 1998;74(4): 494-522.

[66] Fisher TM, Farley KB, Gao Y, Bai H, Tse ZTH. Electric vehicle wireless charging technology: A state-of-the-art review of magnetic coupling systems. Wireless Power Transfer. 2014;1(2): 87-96.

[67] Ding P-P, Bernard L, Pichon L, Razek A. Evaluation of 
electromagnetic fields in human body exposed to wireless inductive charging system. IEEE Transactions on Magnetics. 2014;50(2): 1037-1040.

[68] Monteiro V, Gonçalves H, Ferreira JC, Afonso JL. Batteries charging systems for electric and plug-in hybrid electric vehicles. In: Carmo J. (ed.) New Advances in Vehicular Technology and Automotive Engineering. InTech Open; 2012. p. 149-168.

[69] Iyer VM, Gulur S, Bhattacharya S. Variable DC bus control for a bidirectional on-board electric vehicle charger.
In: Proceedings of the 2017 IEEE $6^{\text {th }}$ International Conference on Renewable Energy Research and Applications (ICRERA), 5-8 Nov. 2017, San Diego, California, USA. IEEE; 2017. p. 1041-1046.

[70] Wang X, Jiang C, Lei B, Teng H, Bai HK, Kirtley JL. Power-loss analysis and efficiency maximization of a silicon-carbide MOSFET-based three-phase 10-kW bidirectional EV charger using variable-DC-bus control. IEEE Journal of Emerging and Selected Topics in Power Electronics. 2016;4(3): 880-892. 